\title{
Kualitas Kimia dan Organoleptik Yoghurt yang dibuat Menggunakan Kultur Yoghurt dan Jenis Susu yang Berbeda
}

Astri Mersiana Timo dan Theresia Ika Purwantiningsih ${ }^{\mathrm{b}}$

${ }^{a}$ Fakultas Pertanian, Universitas Timor, Kefamenanu, TTU - NTT, 85613, Indonesia, email: ersiastri@gmail.com

${ }^{b}$ Fakultas Pertanian, Universitas Timor, Kefamenanu, TTU - NTT, 85613, Indonesia, email: theresiaicha@gmail.com

\section{Article Info}

Article history:

Received 13 Mei 2020

Received in revised form 17 Juni 2020

Accepted 05 Juli 2020

DOI:

https://doi.org/10.32938/ja.v5i3.1022

Keywords:

Susu segar

Susu UHT

Susu bubuk

Yoghurt

\section{Abstrak}

Penelitian ini bertujuan untuk mengetahui kualitas kimia dan organoleptik yoghurt yang dibuat menggunakan kultur yoghurt dan jenis susu yang berbeda. Penelitian ini dilaksanakan pada bulan Januari 2020. Bertempat di Laboratorium Fakultas Pertanian Universitas Timor Kefamenanu (untuk pengujian organoleptik yoghurt) dan di Laboratorium Kimia Fakultas Peternakan Universitas Nusa Cendana Kupang (untuk pengujian $\mathrm{pH}$, kadar asam laktat, kadar protein dan kadar lemak). Penelitian menggunakan jenis susu segar, susu UHT (Ultra High Temperature) dan susu bubuk. Rancangan percobaan yang digunakan adalah Rancangan Acak Lengkap (RAL) dengan 3 perlakuan 3 ulangan. Perlakuan terdiri dari R0 = susu segar, R1 = susu UHT dan R2 = susu bubuk. Berdasarkan hasil analisis statistic bahwa penggunaan jenis susu yang berbeda menunjukkan signifikan atau terjadi perbedaan yang nyata $(\mathrm{P}<0,05)$. Penggunaan jenis susu segar dapat memberikan warna yoghurt yang baik yaitu sebesar 1,77 yang menunjukkan yoghurt tersebut berwarna putih kekuningan. Aroma yoghurt yang terbaik terdapat pada jenis susu UHT yaitu sebesar 2,74 yang menunjukkan yoghurt tersebut beraroma khas. Tekstur yoghurt terbaik terdapat pada jenis susu UHT yaitu sebesar 2,30 yang menunjukkan yoghurt tersebut bertekstur agak kental. Tingkat keasaman yoghurt yang terbaik terdapat pada jenis susu UHT yaitu sebesar 3,04 yang menunjukkan yoghurt tersebut memilik tingkat keasaman yang asam. Tingkat kesukaan yoghurt yang baik terdapat pada jenis susu bubuk sebesar 2,37 yang menunjukkan bahwa yoghurt tersebut memiliki tingkat kesukaan yang suka. $\mathrm{pH}$ yoghurt yang terbaik pada jenis susu UHT yaitu sebesar 4,16 . Kadar asam laktat yang terbaik pada jenis susu bubuk yaitu sebesar $0,78 \%$. Kadar protein yang terbaik pada jenis susu segar yaitu sebesar $2,86 \%$ dan kadar lemak yoghurt yang terbaik pada jenis susu bubuk $0,30 \%$. Kesimpulan dari penelitian ini adalah jenis susu UHT adalah jenis susu yang lebih baik digunakan dalam pembuatan yoghurt dibandingkan dengan jenis susu segar dan susu bubuk yang ditinjau dari aroma, tekstur, tingkat keasaman, $\mathrm{pH}$ dan kadar protein.

\section{Pendahuluan}

Ilmu pengetahuan dan teknologi saat ini sangat berkembang dikalangan masyarat, sehingga masyarakat sangat peduli akan kebutuhan gizi bagi tubuh mereka. Oleh sebab itu, masyarakat mulai mengkonsumsi makanan yang mengandung nilai gizi seperti susu. Susu adalah salah satu sumber protein hewani yang memiliki nilai gizi tinggi karena mengandung protein. Komposis utama susu adalah protein, lemak dan laktosa yang berperan sebagai sumber energi, mineral dan vitamin (Saleh, 2004). Susu segar merupakan susu yang dihasilkan dari proses pemerahan secara langsung tanpa ditambah/dikurangi zat lain, ataupun mengalami proses pengolahan. Susu segar rasanya tidak begitu manis karena mengandung protein yang tinggi. Susu segar dapat terkontaminasi oleh mikroorganisme penyebab penyakit yang dapat menular pada manusia. Oleh karena itu, susu harus ditangani secara baik dan memenuhi syarat-syara kualitas SNI (Standarisasi Nasional Indonesia) yang telah ditetapkan serta diperlukan penanganan terhadap susu dengan teknologi pengolahan yang tepat, sehingga susu dapat dimanfaatkan secara optimal. Untuk mencegah susu aga tidak mudah rusak sebelum dikonsumsi dapat dilakukan dengan pengolahan seperti pasteurisasi, sterilisasi dan fermentasi. Salah satu produk pengolahan susu yang dapat dilakukan agar susu tidak mudah rusak yakni melalui proses fermentasi adalah yoghurt.

Yoghurt merupakan suatu produk susu yang difermentasi menggunakan bakteri asam laktat seperti Lactobacillus bulgaricus, Lactobacillus acidophilus dan Streptococcus thermophilus yang sangat menguntungkan (Widowati dan Misgiyarta, 2004). Bakteri Lactobacillus bulgaricus merupakan jenis bakteri gram positif, berbentuk batang, sering membentuk pasangan dan rantai dari selselnya serta dapat mengubah laktosa menjadi asam (Vos et al., 2009). Bakteri Lactobacillus acidophilus adalah bakteri golongan gram positif dan tidak membentuk spora, berbentuk batang panjang serta bersifat anaerob fakultatif dan katalase negatif (Harley dan Prescott, 2002). Bakteri Streptococcus thermophilus merupakan jenis bakteri gram positif yang berbentuk bulat, membentuk rantai serta dapat menghasilkan asam laktat dan membantu mengawetkan susu. Pada proses fermentasi yoghurt dapat menggunakan kultur tunggal dan kultur campuran. Menurut El-Abbassy dan Sitohy (1993), bahwa produk yoghurt yang menggunakan kultur campuran bakteri, memenuhi standa yang ditetapkan oleh Food Standards Australia New Zealand. Kultur campuran dari bakteri asam laktat seperti Lactobacillus bulgaricus dan Streptococcus thermophilus merupakan bakteri yang umum digunakan sebagai kultur starte pada proses fermentasi susu menjadi yoghurt. Ketika digunakan sebagai kultur campuran, kedua bakteri ini bersimbiosis mutualisme, dimana Lactobacillus bulgaricus dapat menghasilkan asam amino dan peptida pendek yang menstimulasi pertumbuhan Streptococcus thermophilus, sedangkan Streptococcus thermophilus menghasilkan asam format yang menunjang pertumbuhan Lactobacillus bulgaricus. Selain itu, Lick et al. (2001) dan Elli et al. (2006) juga menemukan bahwa Lactobacillus bulgaricus dan Sterptococcus thermophilus dapat bertahan hidup setelah melewati saluran pencernaan Menurut Gomez dan Malcata (1999), bahwa Lactobacillus acidophilus merupakan bakteri asam laktat yang dilaporkan memiliki ketahanan yang lebih baik dalam saluran pencernaan manusia.

Yoghurt memiliki bentuk mirip seperti bubur atau es krim. Yoghurt yang baik harus memiliki kualitas kimia dan organoleptik yang baik pula. Menuru Standarisasi Nasional Indonesia (SNI, 2009), bahwa kualitas kimia yoghur seperti pHnya 4-4,5 dan kadar asam laktat $0,5-2,0 \%$, kadar lemak minimal $3,0 \%$ dan kadar protein minimal $2,7 \%$. Untuk mendapatkan yoghurt yang baik harus dilihat juga kualitas organoleptik dari yoghurt seperti warna putih kekuningan, tekstur agak kental atau lunak dan halus, beraroma atau flavour khas dan rasanya asam. Rasa asam yang dimiliki yoghurt menyebabkan sebagian banyak masyarakat tidak menyukai yoghurt. Tetapi yoghurt mengandung beberapa manfaat bagi tubuh yaitu selain memiliki nilai nutris yang baik juga bermanfaat bagi kesehatan tubuh terutama saluran pencernaan yaitu dapat menghambat bakteri patogen serta bagi penderita lactose intolerance atau kesulitan untuk mencerna laktosa. Yoghurt dapat dibuat menggunakan susu segar, susu UHT (Ultra High Temperature) dan susu bubuk. Perbandingan antara yoghurt yang dibuat menggunakan susu segar dan susu UHT yaitu: yoghurt yang dibuat menggunakan susu segar pHnya lebih tinggi dari susu UHT dan kadar asam laktat susu segar lebih rendah dari susu UHT. Tingginya kadar asam laktat berarti kadar laktosa pada susu rendah (Prayitno, 2006), sehingga dapat dikatakan bahwa susu segar memiliki kadar laktosa yang lebih tinggi daripada susu UHT. Hal ini dikarenakan susu UHT adalah susu sapi berlemak yang telah mengalami pasteurisasi pada suhu yang tinggi 135 $155^{\circ} \mathrm{C}$ dalam waktu yang singkat, yaitu 3-5 detik. Pasteurisasi pada suhu tingg dapat menginaktifkan enzim lactase, sehingga tidak mampu berperan dalam menguraikan laktosa menjadi asam laktat (Saleh, 2011). Susu bubuk melalui proses pengeringan susu segar yang telah dipasteurisasi, dengan atau tanpa penambahan vitamin, mineral dan bahan tambahan pangan yang diizinkan. Jenis susu full cream merupakan salah satu hasil pengolahan susu yang dapat dimanfaatkan dalam pembuatan yoghurt. Oleh karena itu, untuk mengatasi ketersediaan susu segar kita dapat memanfaatkan susu olahan seperti susu UHT dan susu bubuk sebagai pengganti susu segar. Tujuan penelitian ini adalah untuk mengetahui kualitas kimia dan organoleptik yang dibuat menggunakan jenis susu yang berbeda

\section{Metode}

\subsection{Lokasi dan Waktu Penelitian}

Penelitian ini telah dilaksanakan pada bulan Januari 2020. Bertempat di Laboratorium Fakultas Pertanian Universitas Timor Kefamenanu (untuk pengujian organoleptik yoghurt) dan di Laboratorium Kimia Fakultas Peternakan Universitas Nusa Cendana Kupang (untuk pengujian $\mathrm{pH}$, kadar asam laktat, kadar protein dan kadar lemak).

\section{Alat dan Bahan}

Peralatan yang digunakan dalam penelitian ini terdiri dari: kompor panci, saringan, baskom, senduk untuk mengaduk susu, thermometer, toples, gelas ukur, gelas bakker, $\mathrm{pH}$ meter, pipet tetes, mikropipet, botol babcock, labu erlenmeyer, labu kjeldahl, buret, corong kaca, bulp, stirer (pengaduk magnetik), labu destilasi, alat destilasi, filler (karet pengisap), spatula, neraca analitik, penjepit untuk menjepit tabung reaksi, rak tabung reaksi, sentrifuge manual, pemanas listrik dan lemari asam. Bahan yang digunakan dalam penelitian ini adalah susu segar, susu UHT (Ultra High Temperature) full cream, susu bubuk full cream, kultur yoghurt yaitu (Lactobacillus bulgaricus, Lactobacillus acidophilus dan Streptococcus thermophilus), aquadest, larutan $\mathrm{NaOH} 0,1 \mathrm{~N}$ larutan indikator pp (fenolptalein), larutan $\mathrm{H}_{2} \mathrm{SO}_{4}$ pekat, larutan $\mathrm{HCl} 0,01 \mathrm{~N}$ larutan asam borax $2 \%$, pereaksi Selen (Selen mixture) dan indikator BCG-MR.

\subsection{Metode Penelitian}

Penelitian ini bersifat eksperimen dengan rancangan percobaan yang digunakan dalam penelitian ini adalah Rancangan Acak Lengkap (RAL) dengan menggunakan 3 perlakuan dan masing-masing perlakuan diulang 3 kali. Perlakuan terdiri dari:

$\mathrm{R} 0=$ Susu segar 
R1= Susu UHT(Ultra High Temperature)

R2= Susu bubuk

\subsection{Prosedur Penelitian}

Prosedur penelitian terdiri atas 2 bagian yakni prosedur pembuatan yoghurt dan prosedur pengujiaan yoghurt.

\subsubsection{Prosedur pembuatan yoghurt}

1. Alat dan bahan disiapkan

2. Susu sebanyak $1000 \mathrm{ml}$ (1 liter) dituangkan ke dalam panci dan dipanaskan menggunakan kompor dengan api kecil sambil diaduk perlahan. Diperhatikan saat proses pemanasan jangan sampai susunya mendidih dan hangus pada bagian bawah. Proses ini bertujuan untuk mengubah struktur protein susu agar berubah menjadi padat dan mengurangi bakteri yang berada dalam susu.

3. Kemudian gunakan alat thermometer untuk mengukur suhu susu dan apabila suhu susu mencapai $43^{\circ} \mathrm{C}$ susu diangkat dan didinginkan dengan diletakkan panci ke dalam baskom atau wadah yang berisi air sambil diaduk secara perlahan dengan tujuan untuk menurunkan suhu susu.

4. Saat suhu susu sudah mencapai temperatur yang diinginkan yaitu $38^{\circ} \mathrm{C}$, kultur yoghurt (Lactobacillus bulgaricus, Lactobacillus acidophilus dan Streptococcus thermophilus sebanyak $50 \mathrm{ml}$ ) dituangkan ke dalam panci yang berisi susu $1000 \mathrm{ml}$ atau 1 liter tersebut. Susu dan kultur yoghurt diaduk hingga merata secara keseluruhan.

5. Susu yang sudah tercampur dengan kultur yoghurt dipindahkan ke dalam wadah bersih. Wadah ditutup rapat atau ditutup dengan apapun sehingga tidak menyediakan ruang udara bisa masuk agar proses inkubasinya berjalan dengan sempurna.

6. Saat proses inkubasi terjadi, campuran susu dan kultur yoghurt didiamkan agar bakteri tumbuh dan berkembang. Proses ini memakan waktu selama 12 jam. Semakin lama didiamkan maka tingkat keasaman akan semakin tinggi dan tekstur akan menjadi lebih kental.

7. Setelah didiamkan selama 12 jam, yoghurt yang dihasilkan siap untuk dianalisis.

\subsubsection{Prosedur pengujian yoghurt}

Prosedur pengujian yoghurt terbagi menjadi 2 bagian yaitu :

1. Pengujian organoleptik yoghurt

Pengujian organoleptik yoghurt adalah pengujian yang didasarkan pada proses pengindraan. Pengindraan berarti reaksi mental (sensation) jika alat indra mendapat rangsangan (stimulus) dari yoghurt. Reaksi atau kesan yang ditimbulkan karena adanya rangsangan dapat berupa sikap untuk mendekati atau menjauhi, menyukai atau tidak menyukai akan yoghurt penyebab rangsangan. Pengujian organoleptik yoghurt terdiri dari warna, aroma, tekstur, tingkat keasaman dan tingkat kesukaan. Pengujian ini menggunakan 15 orang panelis (dosen dan mahasiswa Fakultas Pertanian Universitas Timor Kefamenanu yang pernah atau sering mengkonsumsi yoghurt dan memiliki pengetahuan tentang yoghurt). Panelis merupakan orang yang bertugas menilai sifat atau kualitas yoghurt berdasarkan kesan subyektif. Ada beberapa syarat yang dimiliki panelis dalam pengujian organoleptik yoghurt, yaitu sebagai berikut:

a) Panelis bukan orang yang ikut membuat produk yoghurt

b) Panelis adalah orang yang mau dengan sukarela dan tanpa paksaan, karena apabila terpaksa maka penilaiannya akan subjektif atau justru hasilnya cenderung memilih yang netral dan asal-asalan

c) Panelis dalam kondisi sehat jasmani dan rohani

d) Panelis memiliki kepekaan indra yang baik terhadap yoghurt (tidak buta warna dan mampu mengenali rasa dasar dari yoghurt)

e) Panelis dipilih sesuai keahliannya (misal panelis yang memang suka yoghurt, sering mengkonsumsi yoghurt dan memiliki pengetahuan tentang yoghurt)

f) Panelis tidak dalam keadaan lapar atau sesaat setelah makan ketika pengujian yoghurt.

Pengujian organoleptik yoghurt dapat dilihat pada Tabel 1.

\section{Pengujian kimia yoghurt sebagai berikut:}

\section{a. Pengujian $\mathrm{pH}$}

Pengukuran $\mathrm{pH}$ dilakukan dengan menggunakan $\mathrm{pH}$ meter. Alat $\mathrm{pH}$ meter distandarisasi terlebih dahulu dengan larutan penyangga (buffer) untuk $\mathrm{pH} 4$ dan $\mathrm{pH} 7$ sesuai kisaran $\mathrm{pH}$ yoghurt (AOAC, 1995). Pengukuran dilakukan dengan $\mathrm{pH}$ meter dicelupkan kedalam sampel. Skala dibaca setelah angka pada $\mathrm{pH}$ meter berada pada posisi yang tetap atau tidak berubah.

b. Pengujian kadar asam laktat

Keasaman dianalisis dengan metode titrasi dengan $\mathrm{NaOH} 0,1 \mathrm{~N}$ dan phenolphthalein $1 \%$ sebagai indikator (AOAC, 2005). Sampel dimasukkan ke dalam labu erlenmeyer, kemudian ditambahkan dengan 4-5 tetes indikator pp (fenolftalein) 1\%. Campuran dititrasi dengan $\mathrm{NaOH} 0,1$ Nsebanyak $50 \mathrm{ml}$ dan titrasi dihentikan apabila telah terjadi perubahan warna merah muda. Jumlah larutan $\mathrm{NaOH} 0,1 \mathrm{~N}$ yang dibutuhkan untuk mentitrasi sampel dicatat. Penghitungan persentase asam laktat menggunakan rumus sebagai berikut :

$\%$ Asam laktat $=\frac{V 1 \times N \times \mathrm{B}}{V 2 \times 1000} \times 100 \%$

Keterangan:

$\mathrm{V} 1=$ Volume $\mathrm{NaOH}(\mathrm{ml})$

$\mathrm{V} 2=$ Volume sampel $(\mathrm{ml})$
$\mathrm{N}=$ Normalitas $\mathrm{NaOH}(0.01 \mathrm{~N})$

$\mathrm{B}=$ Berat molekul asam laktat $(90)$

Tabel 1. Pengujian Organoleptik Yoghurt

\begin{tabular}{|c|c|c|}
\hline \multirow{2}{*}{$\begin{array}{l}\text { Pengujian } \\
\text { Organoleptik }\end{array}$} & \multicolumn{2}{|c|}{ Jenis Penilaian } \\
\hline & Skala Numerik & Skala Hedonik \\
\hline \multirow{4}{*}{ Warna } & 1 & Putih kekuningan \\
\hline & 2 & Kuning \\
\hline & 3 & Kuning tua \\
\hline & 4 & Tidak kuning \\
\hline \multirow{4}{*}{ Aroma } & 1 & Tidak khas \\
\hline & 2 & Agak khas \\
\hline & 3 & Khas \\
\hline & 4 & Sangat khas \\
\hline \multirow{4}{*}{ Tekstur } & 1 & Tidak kental \\
\hline & 2 & Agak kental \\
\hline & 3 & Kental \\
\hline & 4 & Sangat kental \\
\hline \multirow{4}{*}{ Tingkat keasaman } & 1 & Tidak asam \\
\hline & 2 & Agak asam \\
\hline & 3 & Asam \\
\hline & 4 & Sangat asam \\
\hline \multirow{4}{*}{ Tingkat Kesukaan } & 1 & Tidak suka \\
\hline & 2 & Agak suka \\
\hline & 3 & Suka \\
\hline & 4 & Sangat suka \\
\hline
\end{tabular}

c. Pengujian kadar protein

Penentuan kadar protein ditentukan dengan metode Kjeldahl. Pertama sampel dimasukan ke dalam labu kjeldahl. Kemudian ditambahkan pereaksi Selen (Selen mixture) sebanyak setengah ujung spatula dan $20 \mathrm{ml} \mathrm{H}_{2} \mathrm{SO}_{4} 95$ $97 \%$. Lalu ditempatkan pada alat digestasi atau pemanas listrik, panaskan untuk mendestuksi dengan suhu $200-250^{\circ} \mathrm{C}$ selama $2-3$ jam (sampai warnanya hijau jernih). Lalu diencerkan sampai $120 \mathrm{ml}$ dengan aquadest (dilakukan dengan hati-hati dan perlahan, karena akan timbul panas). Kemudian diambil dengan pipet tetes sebanyak $5 \mathrm{ml}$ tersebut dan dimasukkan kedalam alat destilasi. Lalu ditambahkan $10 \mathrm{ml}$ larutan $\mathrm{NaOH} 50 \%$ kedalam sampel dan dibilas dengan aquadest. Destilat ditampung dengan larutan asam borat $2 \%$ dalam labu erlenmeyer yang sudah dibubuhi indikator BCG-MR, sampai volume destilat \pm $30 \mathrm{ml}$. Kemudian destilat tersebut dititrasi dengan $\mathrm{HCl} 0,01 \mathrm{~N}$, sampai terbentuk warna titik akhir merah muda yang tidak hilang dalam 30 detik. $\%$ kadar protein dapatdihitung dengan terlebih dahulu mencari nilai \% $\mathrm{N}$ yang menggunakan persamaan berikut ini:

$\% \mathrm{~N}=\frac{\text { (Volume titrasi contoh-Sampel blanko) }}{\text { Bobot contoh }(\mathrm{mg})} \times 14$ XnHClx $24 \times 100 \%$

$\%$ Kadar protein $=\% \mathrm{~N} \times$ Faktor konversi protein

Keterangan:

$\mathrm{n}=$ Normalitas $\mathrm{H}_{2} \mathrm{SO}_{4}$ untuk titrasi

14= BM nitrogen

Faktor konversi protein $=6.25$

d. Pengujian kadar lemak

Penentuan kadar lemak ditentukan dengan metode Babcock. Sampel dimasukan kedalam botol babcock kemudian ditambahkan tetes demi tetes $\mathrm{H}_{2} \mathrm{SO}_{4}$ pekat $\pm 17,5 \mathrm{ml}$, lalu kocok hingga gumpalan sampel tercampur semua untuk merusak emulsi lemak sehingga lemak akan terkumpul menjadi satu pada bagian atas cairan dengan cara di sentrifuge botol babcocknya selama 10-15 menit. Ditambahkan air panas sampai larutan dalam botol babcock naik hingga leher botol babcock. Kemudian sentrifuge selama 5 menit dan ditambahkan lagi air panas hingga lemak cair terletak dalam kolom pada leher botol babcock yang berskala, lalu sentrifuge sekali lagi. Dimasukkan botol babcock ke dalam air hangat $\left(55-60^{\circ} \mathrm{C}\right)$ selama 3 menit atau lebih. Kemudian keringkan botol babcock dan ukur kolom lemak dari bawah sampai miniskus atau dengan batas pengukur kapiler. Persentase kadar lemak dihitung dengan persamaan:

$\%$ Kadar lemak $=\frac{b \times a}{18,0481}$

Keterangan :

$\mathrm{a}=$ Massa sampel yang dihitung

$\mathrm{b}=$ Volume lemak yang terterapadaalatbabcock

$18.0481=$ Massa sampel

\subsection{Variabel Penelitian}

Variabel yang diamati dalam penelitian ini adalah organoleptik yoghurt yang terdiri dari: warna, aroma, tekstur, tingkat keasaman dan tingkat kesukaan. Kualitas kimia yoghurt yang terdiri dari: $\mathrm{pH}$, kadar asam laktat, kadar protein dan kadar lemak

\subsection{Analisis Data}

Rancangan percobaan yang digunakan dalam penelitian ini adalah Rancangan Acak Lengkap (RAL). Data yang diperoleh dianalisis dengan analisis statistik untuk mengetahui ada dan tidak pengaruh perlakuan dilanjutkan dengan uji Jarak Berganda Duncan untuk melihat perbedaan dengan 
tingkat signifikasi 0,05 . Analisis data parametrik dan non parametrik dilakukan dengan menggunakan SPSS 16.0.

\section{Hasil dan Pembahasan}

\subsection{Kualitas Yoghurt}

Kriteria bahan-bahan yang terkandung dalam jenis susu segar, susu UHT (Ultra High Temperatur) full cream dan susu bubuk full cream berdasarkan Standarisasi Nasional Indonesia (SNI) dapat dilihat pada Tabel 2.

Tabel 2. Kriteria Bahan-Bahan yang Terkandung dalam Jenis Susu Segar, Susu UHT (Ultra High Temperatur) Full Cream dan Susu Bubuk Full Cream Menurut SNI

\begin{tabular}{|c|c|c|c|c|}
\hline \multirow[t]{2}{*}{ No } & \multirow[t]{2}{*}{ Kriteria } & \multicolumn{3}{|c|}{ Jenis Susu } \\
\hline & & Susu Segar & $\begin{array}{l}\text { Susu UHT } \\
\text { Full Cream }\end{array}$ & $\begin{array}{l}\text { Susu bubuk } \\
\text { Full Cream }\end{array}$ \\
\hline 1. & Keadaan: & & & \\
\hline & Warna & $\begin{array}{l}\text { Tidak ada } \\
\text { perubahan }\end{array}$ & Khas, normal & Khas, normal \\
\hline & Bau & Khas, normal & Khas, normal & Khas, normal \\
\hline & Rasa & Khas, normal & Khas, normal & Khas, normal \\
\hline 2. & Kadar lemak & $\operatorname{Min} 3,0 \%$ & Min. $3.0 / 2.0 * \% \mathrm{~b} / \mathrm{b}$ & Min. $26 \% \mathrm{~b} / \mathrm{b}$ \\
\hline 3. & Kadar protein & $2,8 \%$ & Min. $2.7 / 2.0 * \% \mathrm{~b} / \mathrm{b}$ & Min. $23 \% \mathrm{~b} / \mathrm{b}$ \\
\hline $\begin{array}{l}4 . \\
5 .\end{array}$ & $\begin{array}{l}\text { Laktosa } \\
\text { Cemaran logam: }\end{array}$ & Tidak tertera & Tidak tertera & Min. $9,0 \%$ \\
\hline & Timbal $(\mathrm{Pb})$ & $0.02 \mu \mathrm{g} / \mathrm{ml}$ & Maks. $0.02 \mathrm{mg} / \mathrm{kg}$ & Maks. $0.3 \mathrm{mg} / \mathrm{kg}$ \\
\hline & Merkuri (Hg) & $0.03 \mu \mathrm{g} / \mathrm{ml}$ & Maks. $0.03 \mathrm{mg} / \mathrm{kg}$ & Maks. $0.3 \mathrm{mg} / \mathrm{kg}$ \\
\hline & Arsen & $0.1 \mu \mathrm{g} / \mathrm{ml}$ & Maks. $0.1 \mathrm{mg} / \mathrm{kg}$ & Maks. $0.1 \mathrm{mg} / \mathrm{kg}$ \\
\hline & Timah (Sn) & - & Maks. $40.0 \mathrm{mg} / \mathrm{kg}$ & $\begin{array}{c}\text { Maks. } 40.0 / 250^{*} \\
\mathrm{mg} / \mathrm{kg}\end{array}$ \\
\hline & Tembaga $(\mathrm{Cu})$ & - & Maks. $20 \mathrm{mg} / \mathrm{kg}$ & Maks. $20.0 \mathrm{mg} / \mathrm{kg}$ \\
\hline 6. & $\begin{array}{l}\text { Cemaran mikroba: } \\
\text { Jumlah total } \\
\text { (total plate count) }\end{array}$ & $1 \times 10^{6}$ & $<10 / 0,1 \mathrm{ml}$ & $5 \times 10^{4}$ \\
\hline & Caliform & $2 \times 10^{1}$ & 0 & 0 \\
\hline & Eshericha coli $(*)$ & 0 & 0 & 0 \\
\hline & Enterobacteriaceae & $1 \times 10^{2}$ & 0 & $1 \times 10^{1}$ \\
\hline & $\begin{array}{l}\text { Staphylococcus } \\
\text { aureus }\end{array}$ & $1 \times 10^{2}$ & 0 & $1 \times 10^{1}$ \\
\hline & Clostridium $s p$ & 0 & 0 & 0 \\
\hline & Salmonella $s p(* *)$ & Negatif & Negatif & Negatif \\
\hline & Comphylobacter $s p$ & 0 & 0 & 0 \\
\hline & Listeria sp & 0 & 0 & 0 \\
\hline
\end{tabular}

Tidak tertera; Sumber : SNI No: 01-6366-2000, SNI 01-3141-2011.

Yoghurt adalah salah satu produk hasil fermentasi susu seperti susu segar, susu UHT (Ultra High Temperatur), susu bubuk dan jenis susu lainnya dengan penambahan bakteri asam laktat seperti Lactobacillus bulgaricus, Lactobacillus acidophilus dan Streptococcus thermophilus yang sangat bermanfaat bagi kesehatan manusia. Yoghurt yang baik harus memiliki kualitas organoleptik dan kimia yang baik pula, sehingga dapat menarik daya terima konsumen terhadap yoghurt. Kualitas yoghurt sangat dipengaruhi oleh jenis susu yang digunakan dalam pembuatan yoghurt karena bahan-bahan yang terkandung dalam susu tersebut.

\subsubsection{Kualitas Organoleptik Yoghurt}

Pengujian organoleptik adalah penilaian indera atau penilaian sensorik yang merupakan suatu cara penilaian dengan memanfaatkan panca indera manusia untuk mengamati tekstur, warna, bentuk, aroma, rasa suatu produk makanan, minuman ataupun obat (Fitriyono, 2014). Pengujian kualitas organoleptik bertujuan untuk mengetahui daya terima panelis terhadap yoghurt. Pengujian organoleptik ini menggunakan 15 orang panelis yang pernah atau sering mengkonsumsi dan memiliki pengetahuan tentang yoghurt. Penerimaan mencangkup atribut mutu penampilan umum yoghurt seperti warna, aroma, tekstur, tingkat keasaman dan tingkat kesukaan. Tanggapan pribadi panelis tentang kesukaan atau ketidaksukaan terhadap yoghurt tersebut diminta untuk diungkapkan melalui pemberian nilai (angka) yang telah ditetapkan.

\section{Warna}

Warna pada yoghurt merupakan salah satu penentu utama yoghurt untuk disukai atau tidak oleh konsumen, hal ini dikarenakan respon utama secara fisiologis dan stimulus objektif indra penglihatan lebih refleks dalam menilai (Clarck et al., 2009). Berdasarkan Standarisasi Nasional Indonesia (SNI) 2981: 2009 yoghurt yang baik yaitu memiliki warna putih kekuningan. Rataan warna pada yoghurt dari penggunaan jenis susu yang berbeda dapat dilihat pada Tabel 3.

Hasil analisis statistik dari Tabel 3 dapat terlihat bahwa warna yoghurt sebagai respon dari penggunaan jenis susu yang berbeda menunjukkan signifikan atau adanya pengaruh $(\mathrm{P}<0,05)$. Warna pada yoghurt berkisar antara 1,27-1,80 dengan rataan sebesar 1,57. Warna yoghurt yang terbuat dari jenis susu bubuk full cream yaitu sebesar 1,27 yang menunjukkan bahwa yoghurt tersebut berwarna putih. Sedangkan warna yoghurt yang terbuat dari jenis susu segar yaitu sebesar 1,77 dan pada jenis susu UHT full cream sebesar 1,67 yang menunjukkan bahwa kedua jenis susu tersebut memiliki yoghurt yang berwarna putih kekuningan.

Berdasarkan hasil uji lanjut menunjukkan bahwa yoghurt yang dibuat menggunakan jenis susu segar merupakan yoghurt yang baik, karena yoghurt yang dibuat menggunakan jenis susu segar memiliki warna yoghurt yang sesuai dengan Standarisasi Nasional Indonesia (SNI), yaitu berwarna putih kekuningan, sedangkan jenis susu bubuk full cream tidak berwarna putih kekuningan karena telah ditambahkan berbagai macam bahan seperti susu skim bubuk, vitamin dan mineral sehingga warna yoghurt yang dihasilkan berwarna putih, hal ini sependapat dengan Potter (1986), menyatakan bahwa susu bubuk full cream adalah susu yang dikeringkan hingga sekitar $97 \%$ total zat padatnya, biasanya dalam susu full cream telah ditambahkan berbagai macam vitamin dan mineral.

Tabel 3. Nilai Rataan Warna Yoghurt dari Penggunaan Jenis Susu yang Berbeda

\begin{tabular}{ccccc}
\hline \multirow{2}{*}{ Perlakuan } & \multicolumn{3}{c}{ Ulangan } & \multirow{2}{*}{ Rataan } \\
\cline { 2 - 4 } & 1 & 2 & 3 & \\
\hline $\mathrm{R}_{0}$ & 1,80 & 1,80 & 1,73 & $1,77^{\mathrm{a}}$ \\
$\mathrm{R}_{1}$ & 1,67 & 1,67 & 1,67 & $1,67^{\mathrm{b}}$ \\
$\mathrm{R}_{2}$ & 1,27 & 1,27 & 1,27 & $1,27^{\mathrm{c}}$ \\
Rataan & 1,58 & 1,58 & 1,56 & \\
\hline
\end{tabular}

Keterangan warna yoghurt : (1) putih, (2) putih kuning, (3) kuning (4) kuning tua; Superskrip a, b dan c pada baris rataan menunjukkan signifikan atau adanya pengaruh $(P<0,05)$.

Warna yoghurt yang dihasilkan pada jenis susu bubuk full cream berwarna putih sedangkan pada jenis susu segar dan susu UHT full cream berwarna putih kekuningan, hal ini disebabkan karena perbedaan kandungan vitamin A pada susu. Berdasarkan komposisi pada kemasan susu yaitu jenis susu segar memiliki kandungan vitamin A sebanyak 39\% yang lebih tinggi sehingga warna yoghurt yang dihasilkan yaitu berwarna putih kekuningan sedangkan, pada jenis susu UHT full cream memiliki kandungan vitamin A sebanyak $25 \%$ yang tidak berbeda jauh dari jenis susu segar sehingga yoghurt yang dihasilkan berwarna putih kekuningan. Pada jenis susu bubuk full cream memiliki kandungan vitamin A yang lebih rendah yaitu 20\% oleh karena itu, yoghurt yang dihasilkan berwarna putih. Menurut (Potter, 1986), bahwa warna yoghurt ternyata dipengaruhi oleh makanan yang dikonsumsi oleh ternak Makanan hijauan adalah sumber yang baik bagi beta karoten dimana warna kuning pada karoten tersebut akan terdapat dalam lemak air susu. Hal ini yang menyebabkan mengapa yoghurt dari jenis susu bubuk full cream yang berkomposisi susu skim warnanya cenderung lebih putih karena kandungan lemaknya lebih rendah yaitu $10 \%$ dan dari jenis susu UHT full cream yaitu $12 \%$, sementara karoten yang menyumbangkan warna kuning tersebut berasal dari lemak susu.

\section{Aroma}

Aroma adalah salah satu bentuk penilaian terhadap kualitas yoghurt dengan menggunakan alat indera penciuman. Menurut Standarisasi Nasional Indonesia (SNI) 2981:2009 yoghurt yang baik adalah yoghurt yang beraroma khas. Rataan aroma pada yoghurt dari penggunaan jenis susu yang berbeda dapat dilihat pada Tabel 4

Tabel 4. Nilai Rataan Aroma Yoghurt dari Penggunaan Jenis Susu yang Berbeda

\begin{tabular}{ccccc}
\hline \multirow{2}{*}{ Perlakuan } & \multicolumn{3}{c}{ Ulangan } & \multirow{2}{*}{ Rataan } \\
\cline { 2 - 3 } & 1 & 2 & 3 & \\
\hline $\mathrm{R}_{0}$ & 2,07 & 2,08 & 2,09 & $2,08^{\mathrm{c}}$ \\
$\mathrm{R}_{1}$ & 2,73 & 2,74 & 2,75 & $2,74^{\mathrm{b}}$ \\
$\mathrm{R}_{2}$ & 2,78 & 3,54 & 3,55 & $3,54^{\mathrm{a}}$ \\
Rataan & 2,78 & 2,79 & 2,80 & \\
\hline
\end{tabular}

Keterangan aroma yoghurt: (1) tidak khas, (2) agak khas, (3) khas, (4) sangat khas, Superskrip $a, b$ dan c pada baris rataan menunjukkan signifikan atau adanya pengaruh $(P<0,05)$.

Hasil analisis statistik pada aroma yoghurt sebagai respon dari penggunaan jenis susu yang berbeda menunjukkan signifikan atau adanya pengaruh $(\mathrm{P}<0,05)$. Aroma yoghurt berkisar antara 2,07-3,55 dengan rataan sebesar 2,79. Aroma yoghurt yang terbuat dari jenis susu segar yaitu sebesar 2,08 yang menunjukkan bahwa yoghurt tersebut beraroma agak khas, sedangkan aroma yoghurt yang terbuat dari jenis susu UHT full cream yaitu sebesar 2,74 yang menunjukkan bahwa yoghurt tersebut beraroma khas. Aroma yoghurt yang terbuat dari jenis susu bubuk full cream yaitu sebesar 3,54 yang menunjukkan bahwa yoghurt tersebut beraroma sangat khas.

Berdasarkan hasil uji lanjut menunjukkan bahwa yoghurt yang dibuat menggunakan jenis susu bubuk full cream merupakan yoghurt yang baik, karena yoghurt yang dibuat menggunakan jenis susu bubuk full cream memiliki aroma yoghurt yang sangat khas dan sesuai dengan Standarisasi Nasional Indonesia (SNI). Aroma pada yoghurt dipengaruhi oleh asam laktat, sisa-sisa asetaldehid, diasetil, asam asetat dan bahan-bahan mudah menguap lainnya setelah proses fermentasi. Menurut Oberman (1985), bahwa kandungan 
karbohidrat yang tinggi ini digunakan oleh bakteri asam laktat sebagai sumber substrat untuk memproduksi asam laktat, sehingga asam laktat yang dihasilkan pada yoghurt dari susu akan semakin tinggi dan $\mathrm{pH}$ yang dihasilkan juga semakin rendah. Aroma pada yoghurt dipengaruhi oleh asam laktat yang dihasilkan. Menurut Irkin dan Eren (2008), bahwa Lactobacillus bulgaricus lebih berperan pada pembentukan aroma, sedangkan Streptococuss thermophiles lebih berperan pada pembentukan cita rasa yoghurt. Berdasarkan komposisi pada kemasan susu, jenis susu UHT full cream memiliki kandungan karbohidrat sebesar 12 gram yang lebih tinggi dari jenis susu bubuk full cream, yaitu sebesar 10 gram dan jenis susu segar sebesar 4,75 gram. Aroma yoghurt pada jenis susu segar agak khas karena memiliki kandungan karbohidrat yang lebih rendah, sedangkan kandungan karbohidrat dari jenis susu UHT full cream beraroma agak khas dan jenis susu bubuk full cream tidak berbeda jauh, sehingga aroma yoghurt yang dihasilkan yaitu beraroma sangat khas. Akan tetapi, jenis susu bubuk full cream memiliki yoghurt yang beraroma sangat khas dengan kandungan karbohidrat yang lebih rendah dari jenis susu UHT full cream hal ini disebabkan, karena pada jenis susu bubuk full cream memiliki kandungan gula $10 \mathrm{~g}$ sedangkan pada jenis susu UHT full cream tidak memiliki kandungan gula. Kandungan gula tersebut dapat dimanfaatkan untuk pembentukan aroma yoghurt hal inilah yang menyebabkan aroma jenis susu bubuk full cream sangat khas.

\section{Tekstur}

Tekstur yoghurt adalah salah satu sifat yang nampak pada permukaan yoghurt yang dapat dilihat dan diraba. Tekstur dari yoghurt dapat menentukan kualitas dari yoghurt tersebut. Menurut Standarisasi Nasional Indonesia (SNI) 2981: 2009 yoghurt yang baik adalah yoghurt yang memiliki tekstur kental. Rataan tekstur pada yoghurt dari penggunaan jenis susu yang berbeda dapat dilihat pada Tabel 5 .

Tabel 5. Nilai Rataan Tekstur Yoghurt dari Penggunaan Jenis Susu yang Berbeda

\begin{tabular}{ccccc}
\hline \multirow{2}{*}{ Perlakuan } & \multicolumn{3}{c}{ Ulangan } & \multirow{2}{*}{ Rataan } \\
\cline { 2 - 4 } & 1 & 2 & 3 & \\
\hline $\mathrm{R}_{0}$ & 1,13 & 1,26 & 1,40 & $1,26^{\mathrm{c}}$ \\
$\mathrm{R}_{1}$ & 2,26 & 2,33 & 2,33 & $2,30^{\mathrm{b}}$ \\
$\mathrm{R}_{2}$ & 3,80 & 3,80 & 3,73 & $3,77^{\mathrm{a}}$ \\
Rataan & 2,40 & 2,46 & 2,49 & \\
\hline
\end{tabular}

Keterangan tekstur yoghurt: (1) tidak kental, (2) agak kental, (3) kental, (4) sangat kental, Superskrip $a, b$ dan c pada baris rataan menunjukkan signifikan atau adanya pengaruh $(P<0,05)$

Hasil analisis statistik pada Tabel 5 terlihat bahwa pada tekstur yoghurt sebagai respon dari penggunaan jenis susu yang berbeda menunjukkan signifikan atau adanya pengaruh $(\mathrm{P}<0,05)$. Tekstur yoghurt berkisar antara 1,13-3,80 dengan rataan sebesar 2,45. Tekstur yoghurt yang terbuat dari jenis susu segar yaitu sebesar 1,26 yang menunjukkan bahwa yoghurt tersebut memiliki tekstur yang tidak kental, sedangkan tekstur yoghurt yang terbuat dari jenis susu UHT full cream sebesar 2,30 yang menunjukkan bahwa yoghurt tersebut bertekstur agak kental dan tekstur yoghurt yang terbuat dari jenis susu bubuk full cream yaitu sebesar 3,77 yang menunjukkan bahwa yoghurt tersebut bertekstur sangat kental.

Berdasarkan hasil uji lanjut menunjukkan bahwa yoghurt yang dibuat menggunakan jenis susu bubuk full cream merupakan yoghurt yang baik karena, memiliki tekstur yang sesuai dengan Standarisasi Nasional Indonesia (SNI) yaitu kental. Menurut Winarno dan Fernandes (2007), menyatakan bahwa kekentalan dipengaruhi oleh total padatan yang terdapat dalam susu fermentasi. Total padatan dalam susu juga berperan untuk pembentukan tekstur dan aroma yoghurt yang baik. Dalam hal ini laktosa, glukosa, galaktosa pada susu fermentasi diurai oleh bakteri asam laktat sehingga mempengaruhi kekentalan susu fermentasi. Berdasarkan Standarisasi Nasional Indonesia (SNI) Jenis susu bubuk full cream memiliki kandungan laktosa yaitu min. 9,0\% sehingga, kandungan laktosa tersebut dapat diurai bakteri asam laktat untuk menghasilkan kekentalan pada yoghurt sedangkan, pada jenis susu segar dan susu UHT full cream tidak memiliki kandungan laktosa dalam susu sehingga yoghurt tidak sesuai dengan SNI. Menurut Gilliland (1986), bahwa beberapa faktor yang mempengaruhi tekstur yoghurt adalah perlakuan pada susu sebelum diinokulasikan, ketersediaan nutrisi, bahan-bahan pendorong, produksi metabolis oleh lactobacillus, interaksi dengan bakteri biakan lainnya, penanganan bakteri sebelum digunakan dan juga ada atau tidaknya antibiotika dalam susu.

\section{Tingkat Keasaman}

Tingkat keasaman adalah suatu penilaian yang dipengaruhi oleh rasa yoghurt yang diamati yaitu melalui pemberian yoghurt polos (tanpa ditambahi perasa apapun) kepada panelis. Yoghurt biasanya memiliki cita rasa asam menyegarkan yang tajam. Berdasarkan Standarisasi Nasional Indonesia (SNI) 2981: 2009 yoghurt yang baik adalah yoghurt yang memiliki tingkat keasaman yang asam. Rataan tingkat keasaman pada yoghurt dari penggunaan jenis susu yang berbeda dapat dilihat pada Tabel 6 .

Dari Tabel 6 dapat dilihat bahwa hasil analisis statistik pada tingkat keasaman yoghurt sebagai respon dari penggunaan jenis susu yang berbeda menunjukkan signifikan atau adanya pengaruh $(\mathrm{P}<0,05)$. Tingkat keasaman yoghurt berkisar antara 2,66-3,40 dengan rataan sebesar 3,03.

Tabel 6. Nilai Rataan Tingkat Keasaman Yoghurt dari Penggunaan Jenis Susu yang Berbeda

\begin{tabular}{ccccc}
\hline \multirow{2}{*}{ Perlakuan } & \multicolumn{3}{c}{ Ulangan } & \multirow{2}{*}{ Rataan } \\
\cline { 2 - 4 } & 1 & 2 & 3 & \\
\hline $\mathrm{R}_{0}$ & 2,73 & 2,73 & 2,66 & $2,70^{\mathrm{c}}$ \\
$\mathrm{R}_{1}$ & 2,93 & 3,13 & 3,06 & $3,04^{\mathrm{b}}$ \\
$\mathrm{R}_{2}$ & 3,26 & 3,40 & 3,33 & $3,33^{\mathrm{a}}$ \\
Rataan & 2,97 & 3,09 & 3,02 & \\
\hline
\end{tabular}

Keterangan tingkat keasaman yoghurt: (1) tidak asam, (2) agak asam, (3) asam, (4) sangat asam; Superskrip $a, b$ dan c pada baris rataan menunjukkan signifikan atau adanya pengaruh $(P<0,05)$.

Tingkat keasaman yoghurt yang terbuat dari jenis susu segar yaitu sebesar 2,70 yang menunjukkan bahwa yoghurt memiliki tingkat keasaman yang agak asam, sedangkan tingkat keasaman yoghurt yang terbuat dari jenis susu UHT full cream yaitu sebesar 3,04 yang menunjukkan bahwa yoghur tersebut memiliki tingkat keasaman yang asam yang tidak berbeda jauh dengan jenis susu bubuk full cream yaitu sebesar 3,33 yang juga menunjukkan bahwa yoghurt tersebut memiliki tingkat keasaman yang asam. Berdasarkan Tabel 7 menerangkan bahwa hasil penelitian tingkat keasaman dari ketiga jenis susu tersebut berada pada kisaran Standarisasi Nasional Indonesia (SNI) yaitu memiliki tingkat keasaman yang asam karena, dalam proses pembuatan yoghurt menggunakan bakteri asam laktat yang sama (Lactobacillus bulgaricus, Lactobacillus acidophilus dan Streptococcus thermophilus). Ketiga bakteri in akan bekerja untuk menurunkan $\mathrm{pH}$ dan meningkatkan asam laktat sehingga yoghurt yang dihasilkan menjadi asam.

Berdasarkan hasil uji lanjut menunjukkan bahwa yoghurt yang dibuat menggunakan jenis susu bubuk full cream merupakan jenis susu yang baik dalam pembuatan yoghurt, karena berdasarkan komposisi pada kemasan susu, jenis susu bubuk full cream memiliki kandungan gula seperti sukrosa sebanyak $10 \%$ dan laktosa sebanyak min. 9,0\%, sedangkan pada jenis susu segar dan jenis susu UHT full cream tidak memiliki kandungan sukrosa dan laktosa. Oleh karena itu, jenis susu bubuk full cream memiliki tingkat keasaman yang asam. Balia et al. (2011), menyatakan bahwa rasa asam yang disukai panelis sangat dipengaruhi oleh komponen flavour yang dihasilkan oleh bakteri starter yang digunakan, selain itu sukrosa yang ditambahkan dalam pembuatan produk susu fermentasi akan terhidrolisis menjadi komponen yang lebih sederhana yaitu glukosa dan fruktosa. Semakin tingginya laktosa yang dihasil dari jenis susu dapat meningkatkan pula asam laktat yang terbentuk yang menyebabkan rasa yoghurt tersebut terasa asam (Triyono, 2010).

\section{Tingkat Kesukaan}

Tingkat kesukaan pada panelis berbeda-beda karena cita rasa sangat menentukan selera dan daya terima panelis. Peran rasa dalam mempengaruhi selera dan daya terima konsumen sangat besar. Flavour atau rasa adalah rangsangan syaraf yang dihasilkan oleh yoghurt yang dimasukkan kedalam mulut, dirasakan terutama oleh syaraf rasa, bau dan oleh reseptor-reseptor yang ada dalam mulut. Rataan tingkat kesukaan pada yoghurt dari penggunaan jenis susu yang berbeda dapat dilihat pada Tabel 7 .

Tabel 7. Nilai Rataan Tingkat Kesukaan Yoghurt dari Penggunaan Jenis Susu yang Berbeda

\begin{tabular}{ccccc}
\hline \multirow{2}{*}{ Perlakuan } & \multicolumn{3}{c}{ Ulangan } & \multirow{2}{*}{ Rataan } \\
\cline { 2 - 3 } & 1 & 2 & 3 & \\
\hline $\mathrm{R}_{0}$ & 1,86 & 1,73 & 1,80 & $1,79^{\mathrm{b}}$ \\
$\mathrm{R}_{1}$ & 1,93 & 1,86 & 1,86 & $1,88^{\mathrm{b}}$ \\
$\mathrm{R}_{2}$ & 2,26 & 2,40 & 2,46 & $2,37^{\mathrm{a}}$ \\
Rataan & 2,02 & 2,00 & 2,04 &
\end{tabular}

Keterangan tingkat kesukaan yoghurt: (1) tidak suka, (2) agak suka, (3) suka, (4) sangat suka; Superskrip a dan b pada baris rataan menunjukkan signifikan atau adanya pengaruh $(P<0,05)$.

Hasil analisis statistik pada tingkat kesukaan yoghurt sebagai respon dari penggunaan jenis susu yang berbeda menunjukkan signifikan atau adanya pengaruh $(\mathrm{P}<0,05)$. Tingkat kesukaan pada yoghurt berkisar antara $1,73-2,46$ dengan rataan sebesar 2,02. Tingkat kesukaan pada yoghurt yang terbuat dari jenis susu segar, susu UHT full cream dan susu bubuk full cream yaitu sebesar 1,79 dan 1,88 dan 2,37 yang menunjukkan bahwa yoghurt tersebut memiliki tingkat kesukaan yang agak suka.

Berdasarkan hasil uji lanjut menunjukkan bahwa yoghurt yang dibua menggunakan jenis susu bubuk full cream merupakan yoghurt yang baik, karena berdasarkan komposisi pada kemasan susu bahwa pada jenis susu bubuk full cream telah diberi bahan tambahan seperti gula sebanyak $10 \%$ sedangkan pada jenis susu segar dan susu UHT full cream tidak diberi bahan tambahan seperti gula. Semakin tinggi kadar gula yang ditambahkan ke dalam yoghurt, semakin tinggi tingkat kesukaan panelis terutama terhadap rasa dan aroma yoghurt sehingga, para penelis lebih menyukai yoghurt yang terbuat dari jenis susu bubuk full cream jika dibandingkan dengan yoghurt yang terbuat jenis susu segar dan jenis susu UHT full cream. Tingkat kesukaan para panelis sangat menentukan rasa, selera dan daya terima terhadap yoghurt. Menurut 
Naruki dan Kanoni (1992), menyatakan bahwa peran rasa dapat mempengaruhi selera dan daya terima konsumen sangat besar. Flavour atau rasa adalah rangsangan syaraf yang dihasilkan terutama oleh syaraf rasa, bau dan oleh reseptor-reseptor yang ada dalam mulut. Menurut Vinderolla et al. (2002), bahwa hal yang berperan penting dalam penerimaan atau kesukaan konsumen terhadap suatu produk yaitu karakteristik sensori.

\subsubsection{Kualitas Kimia Yoghurt}

Pengujian kualitas kimia adalah pengujian yang dilakukan dengan tujuan untuk mengetahui kandungan kimia dari yoghurt yang dihasilkan. Pengujian kimia yoghurt terdiri dari: $\mathrm{pH}$ (potensial hidrogen), kadar asam laktat, kadar protein dan kadar lemak.

\section{pH}

Nilai $\mathrm{pH}$ adalah derajat keasaman yang digunakan untuk menyatakan tingkat keasaman atau kebasaan yang dimiliki oleh suatu larutan seperti yoghurt. Nilai $\mathrm{pH}$ dapat dipengaruhi oleh pertumbuhan bakteri asam laktat dalam proses fermentasi yoghurt (Buckle et al., 2010). Berdasarkan Standarisasi Nasional Indonesia (SNI) 2981: 2009 pH yoghurt yaitu 4-4,5. Rataan $\mathrm{pH}$ pada yoghurt dari penggunaan jenis susu yang berbeda dapat dilihat pada Tabel 8 .

Tabe 8. Nilai Rataan $\mathrm{pH}$ Yoghurt dari Penggunaan Jenis Susu yang Berbeda

\begin{tabular}{ccccc}
\hline \multirow{2}{*}{ Perlakuan } & \multicolumn{3}{c}{ Ulangan } & \multirow{2}{*}{ Rataan } \\
\cline { 2 - 4 } & 1 & 2 & 3 & \\
\hline $\mathrm{R}_{0}$ & 4,37 & 4,35 & 4,34 & $4,35^{\mathrm{b}}$ \\
$\mathrm{R}_{1}$ & 4,17 & 4,16 & 4,17 & $4,16^{\mathrm{c}}$ \\
$\mathrm{R}_{2}$ & 4,44 & 4,41 & 4,41 & $4,42^{\mathrm{a}}$ \\
Rataan & 4,33 & 4,31 & 4,31 & \\
\hline
\end{tabular}

Keterangan pH yoghurt : Superskrip $a, b$ dan c pada baris rataan menunjukkan signifikan
atau adanya pengaruh $(P<0,05)$.

Berdasarkan hasil analisis statistik pada $\mathrm{pH}$ yoghurt sebagai respon dari penggunaan jenis susu yang berbeda menunjukkan signifikan atau adanya pengaruh $(\mathrm{P}<0,05)$. $\mathrm{pH}$ pada yoghurt berkisar antara 4,35-4,42 dengan rataan sebesar 4,13. pH pada yoghurt yang terbuat dari jenis susu sugar, susu UHT full cream dan susu bubuk full cream yaitu sebesar 4,35 dan 4,16 dan 4,42 yang menunjukkan bahwa ketiga $\mathrm{pH}$ yoghurt hasil penelitian berada dikisaran Standarisasi Nasional Indonesia (SNI). Hal ini disebabkan karena dalam proses pembuatan yoghurt menggunakan bakteri asam laktat yang sama (Lactobacillus bulgaricus, Lactobacillus acidophilus dan streptococcus thermophilus). Ketiga bakteri ini akan bekerja untuk menurunkan $\mathrm{pH}$ yoghurt, sehingga $\mathrm{pH}$ yoghurt sesuai dengan Standarisasi Nasional Indonesia (SNI).

Berdasarkan hasil uji lanjut menunjukkan bahwa yoghurt yang dibuat menggunakan jenis susu bubuk full cream merupakan yoghurt yang baik karena, memiliki kandungan laktosa yang dapat memproduksi bakteri asam laktat yang lebih banyak. Menurut Surono (2004), bahwa fermentasi melibatkan metabolisme laktosa, disakharida dalam susu menjadi asam laktat dan fermentasi yang baik apabila $\mathrm{pH}$ yoghurt rendah. Berdasarkan Standarisasi Nasional Indonesia (SNI), bahwa jenis susu bubuk full cream memiliki $\mathrm{pH}$ yoghurt yang lebih tinggi karena, memiliki kandungan mikroorganisme seperti bakteri Total plate count $\left(5 \times 10^{4}\right)$, Entero bacteriaceae $\left(1 \times 10^{1}\right)$ dan Staphylococcus aureus $\left(1 \times 10^{1}\right)$. Pada jenis susu segar memiliki $\mathrm{pH}$ yoghurt yang lebih tinggi dari jenis susu UHT full cream karena, memiliki kandungan mikroorganisme seperti bakteri Total plate count $\left(1 \times 10^{6}\right)$, Coliform $\left(2 \times 10^{1}\right)$, Entero bacteriaceae $\left(1 \times 10^{2}\right)$ dan Staphylococcus aureus $\left(1 \times 10^{2}\right)$. Pada jenis susu UHT full cream hanya memiliki kandungan mikroorganisme Total plate count $(<10 / 0,1 \mathrm{ml})$ sehingga bakteri asam laktat dapat bekerja untuk menurunkan $\mathrm{pH}$ yoghurt. Oleh karena itu, jenis susu UHT full cream memiliki $\mathrm{pH}$ yang lebih rendah dari jenis susu segar dan jenis susu bubuk full cream. Menurut Tamime dan Robinson (1989), bahwa jenis susu yang digunakan menentukan $\mathrm{pH}$ yoghurt, terutama jumlah mikroba hidup dan keasaman yoghurt.

Menurut Bottazi (1983), bahwa nilai $\mathrm{pH}$ berbanding terbalik dengan nilai total asam tertitrasi sehingga dengan semakin tinggi nilai total asam tertitrasi, maka semakin rendah nilai $\mathrm{pH}$. Oleh karena itu, nilai $\mathrm{pH}$ yang rendah dengan total asam tertitrasi tinggi adalah terbaik pertumbuhannya dalam usus lebih cepat. Bakteri probiotik terutama Lactobacillus acidophilus apabila dikombinasikan dengan bakteri Streptococus thermophilus dan Lactobacillus bulgaricus dapat menghasilkan yoghurt dengan $\mathrm{pH}$ yang lebih rendah karena mampu memfermentasi gula menjadi asam laktat dengan cepat. Menurut Yildiz (2010), pada yoghurt bakteri Lactobacillus achidophilus mampu meningkatkan keasaman dengan cepat dan menghasilkan nilai $\mathrm{pH}$ dibawah 4. Dilanjutkan oleh Mulyani et al. (2008), bahwa nilai pH menurun seiring dengan menurunnya aktivitas bakteri, ditandai dengan semakin berkurangnya jumlah bakteri asam laktat yang masih hidup.

\section{Kadar Asam Laktat}

Kandungan asam laktat adalah jumlah asam laktat yang terbentuk selama proses fermentasi yang merupakan hasil pemecahan karbohidrat terbentuk oleh bakteri asam laktat (Afriani, 2010). Menurut Widodo (2002), bahwa asam laktat dari yoghurt dapat merangsang gerakan peristaltik, hampir pada semua bagian pada saluran pencernaan, selain itu asam laktat dapat mengurangi atau membunuh bakteri patogen dan menekan produksi senyawa-senyawa berbahaya yang diproduksi oleh bakteri patogen. Berdasarkan Standarisasi Nasional Indonesia (SNI 01- 2981:2009) kadar asam laktat yoghurt yang baik adalah sebesar $0,5-2,0 \%$. Rataan kadar asam laktat pada yoghurt dari penggunaan jenis susu yang berbeda dapat dilihat pada Tabel 9 .

Tabel 9. Nilai Rataan Kadar Asam Laktat Yoghurt dari Penggunaan Jenis Susu yang Berbeda (\%)

\begin{tabular}{|c|c|c|c|c|}
\hline \multirow{2}{*}{ Perlakuan } & \multicolumn{3}{|c|}{ Ulangan } & \multirow{2}{*}{ Rataan } \\
\hline & 1 & 2 & 3 & \\
\hline $\mathrm{R}_{0}$ & 0,675 & 0,720 & 0,720 & $0,70^{\mathrm{b}}$ \\
\hline $\mathrm{R}_{1}$ & 0,720 & 0,675 & 0,675 & $0,69^{\mathrm{c}}$ \\
\hline $\mathrm{R}_{2}$ & 0,765 & 0,810 & 0,765 & $0,78^{\mathrm{a}}$ \\
\hline Rataan & 0,72 & 0,74 & 0,74 & \\
\hline
\end{tabular}
menunjukkan signifikan atau adanya pengaruh $(P<0,05)$.

Hasil analisis statistik pada kadar asam laktat yoghurt sebagai respon dari penggunaan jenis susu yang berbeda menunjukkan signifikan atau adanya pengaruh $(\mathrm{P}<0,05)$. Kadar asam laktat yoghurt berkisar antara $0,675 \%-0,810 \%$ dengan rataan sebesar $0,73 \%$. Kadar asam laktat pada yoghurt yang terbuat dari jenis susu sugar, susu UHT full cream dan susu bubuk full cream yaitu sebesar $0,70 \%$ dan $0,69 \%$ dan $0,78 \%$ yang menunjukkan bahwa yoghurt memiliki kadar asam laktat yang berada dikisaran Standarisasi Nasional Indonesia (SNI), karena dalam proses pembuatan yoghurt menggunakan bakteri asam laktat yang sama (Lactobacillus bulgaricus, Lactobacillus acidophilus dan streptococcus thermophilus).

Berdasarkan hasil uji lanjut menunjukkan bahwa jenis susu bubuk full cream merupakan jenis susu yang baik untuk digunakan dalam pembuatan yoghurt, karena memiliki kandungan laktosa yang lebih tinggi (min. 9,0\%) sehingga, menghasilkan kadar asam laktat yang lebih tinggi yaitu sebesar $0.78 \%$. Menurut Prayitno (2006), bahwa perbedaan kadar asam laktat in diduga karena perbedaan kandungan laktosa pada jenis bahan dasar susu yang berbeda, sehingga mempengaruhi laju pemecahan laktosa dan sintesis asam laktat. Jenis susu UHT full cream memiliki kadar asam laktat yang tidak berbeda jauh dari jenis susu segar karena, tidak memiliki kandungan laktosa dalam susu. Jenis susu UHT full cream memiliki kadar asam laktat yang lebih rendah hal ini dikarenakan, jenis susu UHT full cream melalui proses pasteurisasi yang tinggi dapat menghambat enzin lactase untuk menghasilkan asam laktat. Menurut Saleh (2011), bahwa pasteurisasi pada suhu tinggi dapat menginaktifkan enzim lactase, sehingga tidak mampu berperan dalam menguraikan laktosa menjadi asam laktat.

\section{Kadar Protein}

Protein merupakan suatu zat makanan yang amat penting bagi tubuh karena zat ini di samping berfungsi sebagai bahan bakar dalam tubuh juga berfungsi sebagai zat pembangun dan pengatur. Protein adalah sumber asamasam amino yang mengandung unsur-unsur $\mathrm{C}, \mathrm{H}, \mathrm{O}$ dan $\mathrm{N}$ yang tidak dimiliki oleh lemak atau karbohidrat (Winarno, 2002). Menurut Standar Nasional Indonesia (SNI 2981:2009) kadar protein minimal yang harus ada pada yoghurt adalah sebesar $2,7 \%$.Rataan kadar protein pada yoghurt dari penggunaan jenis susu yang berbeda dapat dilihat pada Tabel 10 .

Tabel 10. Nilai Rataan Kadar Protein Yoghurt dari Penggunaan Jenis Susu yang Berbeda (\%)

\begin{tabular}{ccccc}
\hline \multirow{2}{*}{ Perlakuan } & \multicolumn{3}{c}{ Ulangan } & \multirow{2}{*}{ Rataan } \\
\cline { 2 - 3 } & 1 & 2 & 3 & \\
\hline $\mathrm{R}_{0}$ & 2,817 & 2,850 & 2,844 & $2,84^{\mathrm{a}}$ \\
$\mathrm{R}_{1}$ & 1,871 & 1,884 & 2,060 & $1,93^{\mathrm{b}}$ \\
$\mathrm{R}_{2}$ & 2,855 & 2,893 & 2,857 & $2,86^{\mathrm{a}}$ \\
Rataan & 2,51 & 2,54 & 2,59 & \\
\hline
\end{tabular}

Keterangan kadar protein yoghurt: Superskrip a dan b pada baris rataan menunjukkan signifikan atau adanya pengaruh $(P<0,05)$.

Dari Tabel 10 dapat dilihat bahwa hasil analisis statistik kadar protein pada yoghurt sebagai respon dari penggunaan jenis susu yang berbeda menunjukkan signifikan atau adanya pengaruh $(\mathrm{P}<0,05)$. Kadar protein yoghurt berkisar antara 1,871\%-2,893\% dengan rataan sebesar 2,55\%. Kadar protein pada yoghurt yang terbuat dari jenis susu sugar, susu UHT full cream dan susu bubuk full cream yaitu sebesar 2,84\%dan 1,93\% dan 2,86\%. Berdasarkan Tabel 10 dapat menerangkan bahwa kadar protein yoghurt hasil penelitian yang menggunakan jenis susu segar dan susu bubuk full cream berada dikisaran Standarisasi Nasional Indonesia (SNI), sedangkan kadar protein dari jenis susu UHT full cream tidak sesuai dengan SNI.

Berdasarkan hasil uji lanjut menunjukkan bahwa yoghurt yang baik adalah yoghurt yang dibuat menggunakan jenis susu bubuk full cream karena, memiliki kandungan gula sebanyak 10 gram sehingga kadar proteinnya lebih tinggi yaitu sebesar 2,86 dan sesuai dengan Standarisasi Nasional Indonesia (SNI). Menurut Salminen (1993) semakin meningkat energi yang terdapat di dalam yoghurt semakin meningkat aktifitas metabolisme atau reaksi enzymatis dan kimia yang di hasilkan. Semakin tinggi penambahan gula terjadi peningkatan kadar protein yoghurt. Penambahan gula masih terjadi aktifitas Lactobacillus untuk mensintesa protein. Pada jenis susu UHT full cream 
memiliki kadar protein yang lebih rendah dan tidak sesuai dengan SNI karena, jenis susu UHT full cream tidak memiliki kandungan gula dan melalui pasteurisasi dengan suhu yang tinggi sehingga dapat menginaktifkan enzim protease. Menurut Setioningsih (2004), menyatakan bahwa kadar protein dipengaruhi oleh jumlah sel bakteri viabel, kenaikan jumlah sel bakteri viabel akan meningkatkan jumlah enzim yang digunakan untuk memecah protein (aktivitas proteolitik) serta meningkatkan sintesis protein, termasuk di dalamnya enzim pemecah protein (protease). Protein akan dipecah menjadi peptida dan akan dihidrolisis lebih lanjut menjadi asam-asam amino. Hasil pemecahan ini berperan sebagai precursor dalam reaksi enzimatik dan reaksi kimia membentuk flavour. Protein pada membran sel dari bakteri dalam proses analisis dimungkinkan juga ikut terdeteksi sehingga menyebabkan protein dalam minuman cenderung meningkat. Bakteri seperti bakteri asam laktat pada dinding dan membran dikelilingi oleh molekul-molekul besar yang merupakan protein.

\section{Kadar Lemak}

Lemak merupakan sumber nutrisi yang sangat penting karena berfungsi sebagai sumber energi, memperbaiki tekstur dan cita rasa, serta sumber vitamin A, D, Edan K (Winarno, 2002). Menurut Standar Nasional Indonesia (SNI 2981:2009) kadar lemak minimal adalah sebesar 3,0\%. Rataan kadar lemak pada yoghurt dari penggunaan jenis susu yang berbeda dapat dilihat pada Tabe 11.

Tabel 11. Nilai Rataan Kadar Lemak Yoghurt dari Penggunaan Jenis Susu yang Berbeda (\%)

\begin{tabular}{ccccc}
\hline \multirow{2}{*}{ Perlakuan } & \multicolumn{3}{c}{ Ulangan } & \multirow{2}{*}{ Rataan } \\
\cline { 2 - 4 } & 1 & 2 & 3 & \\
\hline $\mathrm{R}_{0}$ & 0,24 & 0,25 & 0,25 & $0,25^{\mathrm{b}}$ \\
$\mathrm{R}_{1}$ & 0,22 & 0,23 & 0,23 & $0,23^{\mathrm{c}}$ \\
$\mathrm{R}_{2}$ & 0,30 & 0,31 & 0,29 & $0,30^{\mathrm{a}}$ \\
Rataan & 0,25 & 0,26 & 0,26 & \\
\hline
\end{tabular}

Keterangan kadar lemak yoghurt: Superskrip a, $b$ dan c pada baris rataan menunjukkan signifikan atau adanya pengaruh $(P<0,05)$.

Hasil analisis statistik kadar lemak pada yoghurt sebagai respon dari penggunaan jenis susu yang berbeda menunjukkan signifikan atau adanya pengaruh $(\mathrm{P}<0,05)$. Kadar lemak pada yoghurt berkisar antara $0,22 \%-0,310 \%$ dengan rataan sebesar $0,26 \%$. Kadar lemak pada yoghurt yang terbuat dari jenis susu sugar, susu UHT full cream dan susu bubuk full cream yaitu sebesar $0,25 \%$ dan $0,23 \%$ dan $0,30 \%$. Berdasarkan Tabel 16 dapat menerangkan bahwa hasil penelitian ketiga jenis susu dalam pembuatan yoghurt kadar lemaknya tidak sesuai dengan standar Standarisasi Nasional Indonesia (SNI), dikarenakan adanya interaksi antara bakteri-bakteri yang digunakan dalam kultur starter dan dengan penambahan bakteri Lactobacillus acidophilus menyebabkan adanya efek inhibisi sehingga kadar lemak yang dihasilkan rendah. Menurut Vinderola et al. (2002), bahwa penggunaan bakteri Lactobacillus acidophilus dapa menghambat pertumbuhan bakteri Lactobacillus bulgaricus, sehingga bakteri Lactobacillus bulgaricus tidak bekerja secara optimal, sedangkan bakteri Lactobacillus acidophilus tidak menunjukkan interaksi yang berarti dengan bakteri Streptococcus. thermophilus. Menurut Setioningsih et al. (2004), menyatakan bahwa setelah fermentasi kadar lemak mengalami penurunan, karena Lactobacillus mampu menurunkan kadar lemak dengan diabsorpsi sebagai sumber energi untuk pertumbuhan. Bakteri asam laktat ini akan memproduksi enzim lipase yang akan menguraikan lemak menjadi asam lemak, selanjutnya asam lemak ini akan diuraikan menjadi senyawa-senyawa yang memiliki aroma khas yoghurt.

Berdasarkan hasil uji lanjut menunjukkan bahwa yoghurt yang dibuat menggunakan jenis susu bubuk full cream merupakan yoghurt yang baik. Menurut Sudarwanto (1996), bahwa kandungan lemak dalam susu bervariasi tergantung dari genetik, pakan, cara pemeliharaan, iklim, masa laktasi dan kesehatan hewan. Menurunnya kadar lemak dalam susu fermentasi ini selain karena faktor diatas juga karena pada proses pasteurisasi masih ada bakteri yang tahan terhadap pemanasan sehingga lemak ini dipakai untuk metabolisme pertumbuhan bakteri tersebut.

\section{Simpulan}

Kesimpulan dari penelitian ini adalah kualitas organoleptik dan kimia yoghurt yang dibuat menggunakan jenis susu yang berbeda cukup bervariasi. Jenis susu yang terbaik terdapat pada jenis susu bubuk full cream yang ditinjau dari aroma, tekstur, tingkat keasaman, tingkat kesukaan, pH, kadar asam laktat, kadar protein dan kadar lemak yoghurt.

\section{Pustaka}

Afriani. 2010. Pengaruh penggunaan starter bakteri asam laktat Lactobacillus plantarum dan Lactobacillus fermentum terhadap total bakteri asam laktat, kadar asam dan nilai pH dadih susu sapi. Jurnal Ilmiah Ilmu-Ilmu Peternakan, 8 (6).

AOAC.1995. Official Methods of Analisys Chemist. Vol.1A. Association of Official Analytical Chemists Inc., Washington.

AOAC.2005. Official methods of analysis, 18 edition. Association of Official Analytical Chemists, Washington.
Badan Standarisasi Nasional Indonesia. 2000. Standarisasi Nasional Indonesia (SNI) 01-6366-2000. Batas Maksimal Cemaran Mikroba dan Batas Maksimum Residu dalam Bahan Makanan Asal Hewan. Jakarta (ID): Badan Standarisasi Nasional.

Balia, R. L., H. Chairunnisa, O. Rachmawandan E.Wulandari.2011. Derajat keasaman dan karakteristik organoleptic produk fermentasi susu kambing dengan penambahan sari kurma yang diinokulasikan berbagai kombinasi starter bakteri asam laktat. Jurnal IlmuTernak,11 (1):49-52.

Bottazi, V. 1983. Other fermented dairy product. In: Biotechnology, Food and Feed Production with Microorganism, Vol. 5.Verlag Chemie, Florida.

Buckle K. A., R. A. Edward, W. R. Day, G. H. Fleet dan M.Wootton.2010. Ilmu Pangan. Universitas Indonesia Press, Jakarta. (Diterjemahkan oleh Hari Purnomo dan Adiono).

Clarck, S.M.Castello, M. A. Drake dan F. Bodyfelt. 2009. The Sensory Evaluation of Diary Products. 2nd ed.Springer.USA.

El-Abbassy, M.Z dan Sitohy, M.1993. Metabolic interaction between Streptococcus thermophilus and Lactobacillus bulgaricus in single and mixed starter yoghurt. Food/Nahrung, 37(1), 53-58.

Elli, M, Callegari, M.L., Ferrari, S, Bessi, Elena, Cattivelli, D., Soldi, S., Morelli, L., Feuillerat, N.G dan Antoine, J. M. 2006. Survival of yogurt bacteria in the human gut. Applied and Environmental Microbiology, 72 (7), 5113-5117.

Fitriyono, A.2014. Teknologi Pangan, Teori Praktis dan Aplikasi. Graha Ilmu. Yogyakarta.

Gilliland, S.E. 1986. Bacterial Starter Cultures for Food. Florida, USA: CRC Press.

Gomez, A.M. P dan Malcata, F.X. 1999. Bifido bacterium spp. and Lactobacillus acidophilus: biological, biochemical, technological and therapeutical properties relevant for use as probiotics. Trends in Food Science \& Technology, $10: 139-157$.

Harley dan Prescott. 2002. Laboratory Exercise in Microbiology. USA. McGraw-Hill Publisher, pp 116.

Irkin, R danEren, U.V. 2008. Research about viable Lactobacillus bulgaricus and Streptococcucthermophylus number \& food science in the market yoghurt. World J. of Dairy, 3(1): 25-28.

Lick. S, Drescher. K dan Heller.K. 2001.Survival of Lactobacillus delbrueckii sub sp. bulgaricus and Streptococcus thermophilus in the terminal ileum of fistulated Göttingen mini pigs. Applied and Environmental Microbiology, 67 (9) : 4137-4143.

Mulyani, S., A.M. Legowo dan A. A. Mahanani. 2008.Viabilitas bakteri asam laktat, keasaman dan waktu pelelehan es krim probiotik menggunakan starter Lactobacillus casei dan Bifido bacterium bifidum. J. Indon. Trop.Anim.Agric, 33 (2) : 120125

Naruki, S dan S. Kanoni.1992. Kimia dan Teknologi Pengolahan Hasil Hewani. Yogyakarta: PAU Pangan dan Gizi Universitas Gadjah Mada.

Oberman, H.1985. Microbiology of Fermented Foods. Vol 2. Elsevier applied Science Publishers, England.

Potter, N.N. 1986. Food Science. New York: Von Nostrand Reinhold Company.

Prayitno. 2006. Kadar Asam Laktat dan Laktosa Yogurt Hasil Fermentasi Menggunakan Barbagai Rasio Jumlah Sel Bakteri dan Persentase Starter. Jurnal Animal Prodution, 8 (2) :131-136.

Puspowardoyo, H.1997. Mikrobiologi Pangan Hewani-Nabati. Yogyakarta: Kanisius.

Robinson, R. K. 1989. Modern Dairy Technology volume 2 : Advances in Milk Production. London: Elsevier Applied Science Publishers.

Saleh, E.2004. Dasar Pengolahan Susu dan Hasil IkutanTernak. Sumatra Utara: Universitas Sumatra Utara Press. Hal: 2-7.

Saleh, E. 2011. Teknologi Pengolahan Susu dan Hasil Ikutan Ternak. Program Studi Produksi Ternak. Fakultas Peternakan USU.

Salminen, S dan Wright, A. 1993. Lactic Acid Bacteria: Microbiology and Functional Aspects. 2nd ed. Mercel Dekker, Inc., New York.

Setioningsih, E., R. Setyaningsih dan A. Susilowati. 2004. Pembuatan Minuman Probiotik dari Susu Kedelai dengan Inokulum Lactobacillus casei, Lactobacillus plantarum dan Lactobacillus Acidophilus. Bioteknologi, 1 (1): 1-6.

Standarisasi Nasional Indonesia. 2009. Pengertian dan Syarat Mutu Susu Fermentasi. No.01-7552-2009. Badan Standarisasi Nasional

Sudarwanto, M. 1996. Komposisi dan Pembentukan Susu. Kursus Singkat Jaminan Mutu dalam Industri Susu. FKH., IPB, Bogor.

Surono, I.S. 2004. Probiotik: Susu Fermentasi dan Kesehatan. PT. Tri Cipta Karya. Jakarta.

Tamime, A.Y dan R.K. Robinson. 1989. Yoghurt: Science Technology. $1_{\mathrm{st}}$ Edition. Pergaman Press London.

Triyono, A. 2010. Mempelajari Pengaruh Maltodekstrin dan Susu Skim terhadap Karakteristik Yoghurt Kacang Hijau (Phaseolus radiatus L.). Seminar rekayasa kimia dan Proses 4-5 Agustus 2010. Balai Besar Pengembangan Teknologi Tepat Guna, Subang.

Vinderola, C. G, P. Mocchiutti dan J. A. Reinheimer. 2002. Interactions Among Lactic Acid Starter and Probiotic Bacteria Used for Fermented Dairy Products. Journal of Dairy Science, 85: 721-729.

Vos, P. De, G, M.Garrity, D.Jones, N.R. Krieg, W. Ludwig, F. A. Rainey, K. H.Schleiferdan W. B. Whitman. 2009. Bergey's Manual Of Systematic 
Bacteriology volume three: Firmicutes. 2nd ed. Springer, Athens: xxvi+1422 hlm.

Widowatidan S. Misgiyarta. 2004. Efektifitas Bakteri Asam Laktat (BAL) Dalam Pembuatan Produk Fermentasi Berbasis Protein/Susu Nabati Prosiding Seminar Hasil Penelitian Rintisan dan Bioteknologi Tanaman, Balai Penelitian Bioteknologi dan Sumberdaya Genetik Pertanian.

Widodo, W. 2002. Bioteknologi Fermentasi Susu. Pusat Pengembangan Bioteknologi. Universitas Mahamadiyah. Malang.

Winarno, F.G. 2002. Ilmu Pangan Gizi. Gramedia Pustaka Utama. Jakarta.

Winarno, F.G dan Fernandez I.E. 2007. Susu dan Produk Fermentasinya. MBrio Press. Bogor.

Yildiz, F. 2010. Development and Manufacture of Yogurt and Other Functional Dairy Products. Taylor and Francis Group, United State. 